\title{
The Impact of EVA Assessment on State-owned Enterprises' Ability of Innovation
}

\author{
Xiaoling Yuan \\ Industry and Economics Department \\ School of Economics and Finance, Xi'an Jiaotong \\ University \\ Xi'an, Shaanxi, China \\ xiaoling@mail.xjtu.edu.cn
}

\author{
Wei Weng \\ Industry and Economics Department \\ School of Economics and Finance, Xi'an Jiaotong \\ University \\ Xi'an, Shaanxi, China \\ wwengxjtu@gmail.com
}

\author{
Zhengda Li \\ Industry and Economics Department \\ School of Economics and Finance, Xi'an Jiaotong University \\ Xi'an, Shaanxi, China \\ aylzd@163.com
}

\begin{abstract}
SASAC (State-owned Assets Supervision and Administration Commission of the State Council) started to use EVA (Enterprise Value Added) assessment as a performance measure on central enterprises in 2010, to guide the way how state-owned enterprises develop, to improve the efficiency of state-owned economy, and to fundamentally improve the ability of innovation. From the perspective of innovation ability, this article has made use of annualized 3year EVA framework, to study how R\&D (Research \& Development) investment by holding companies of central enterprises has affected the EVA performance from 2007 to 2009; furthermore, to analyze the impact of EVA assessment term on innovation ability. Studies have shown that: EVA assessment and $R \& D$ investment are negatively correlated within a given fiscal year thus annual EVA assessment does not encourage enterprise to invest more in $R \& D$ and improve its innovation ability; nevertheless EVA assessment and R\&D investment are positively correlated within any given three fiscal years, thus three year EVA assessment can help improve enterprise innovation ability. Based on the result, we have proposed policy recommendations as far as EVA assessment.
\end{abstract} ability;

Keywords- EVA assessment; R\&D investment; Innovative

\section{INTRODUCTION}

The twelfth five-year plan has recognized advance of science and technology and innovation as important support to accelerate the transformation of economic development, and proposed to strengthen self-innovation ability. It also proposes that the further development should rely on advance of science and technology, improvement of workers quality and innovation of management. R\&D investment affects technology innovation through seed effects, production effects, cause-by effects and self-improvement effects (Lu, Zhiguo, 2005). R\&D investment is positively correlated to new products (Yu, Liping, 2007). R\&D investment has become the main driver to enhance domestic self-innovation especially high-technology level of independent innovation (Li, Ping, 2007). SASAC implemented EVA assessment on central enterprises in 2010, which guided central enterprises to shift from traditional profit management to value management, adapt its extensive operation mode, and focus on improving efficiency of capital use. EVA assessment reflects the guiding ideology of changing development mode and relying on technology innovation to improve development efficiency. What is the impact on enterprise performance due to $R \& D$ investment in different terms? Can annual EVA assessment encourage central enterprises to increase R\&D investment, improve innovation ability and thus enhance operating efficiency of state-owned economy?

\section{THEORETICAL SUMMARY AND RESEARCH HYPOTHESES}

\section{A. Theoretical Summary}

In academic sector, there are a lot of researches of the impact on performance due to $R \& D$ investment. Studies carried out by Griliches (2000), Bosworth and Rogers (2001), Huang and Mishra (2003) show that there is a positive correlation between $R \& D$ investment and enterprise performance. The study of domestic enterprises by Cheng Hongwei also shows the same conclusion. Lin (2006) studied 258 technology-sector listed enterprises in the U.S and found out that R\&D investment was negative correlated to enterprise value. Liang Laixin (2005) studied 150 randomly picked high-technology companies and also found out R\&D investment contributed little to technology assets. Liang Laixin (2010) believed that R\&D investment had significant impact on company performance when enterprises is in growth as well as maturity stage, while R\&D investment had insignificant impact on company performance when enterprises is in recession stage.

In conclusion, first, current indicators for research on innovation performance are mainly accounting indicators (Li, Pin 2007; Liang, Laixin 2010; Mumfordm 2000), 
productivity indicators (Yao, Yang 2001; Tsai K.H. 2005; Tsai Wang 2005), and security indicators (Griliches, 2000; Mishra, Gobeli, 2003; Han 2004). The common drawback of these three performance indicators is that they do not consider the opportunity cost of shareholders' capital Therefore it cannot reflect the actual return of shareholders, neither can it accurately measure elements of production efficiency, which is the advantage of EVA. Second, the term of majority of current research are short (one year), which is based on annual targets, and lacks the research of impact on performance by $\mathrm{R} \& \mathrm{D}$ investments in long term. Third, current domestic research has focused more on listed companies or specific industries, but less on central enterprises who are regarded as the driver of state-owned economic reform. Our research has more practical significance especially under the background of EVA assessment on central enterprises by SASAC. This paper has studied central enterprises during 2007 and 2009, analyzed the relationship between $\mathrm{R} \& \mathrm{D}$ investment in one-year / three-year terms and EVA performance, and discussed how different EVA assessment cycle has affected innovation ability of enterprises.

\section{B. Research Hypotheses}

1) $\quad R \& D$ investment and performance:Technology innovation is a high investment, high risk and long term investment activity. There are many uncertainties in the process of technological innovation. On one hand, enterprises need to increase upfront $R \& D$ investment in order to reduce uncertainties (invest in such as market research, project feasibility study and so on). On the other hand, enterprises need to increase preventive expenses during the $\mathrm{R} \& \mathrm{D}$ process, such as: to run ongoing assessment of project feasibility on a regular basis, to be prepared to deal with uncertainties, and to promptly solve different problems in the process of R\&D. Furthermore, enterprises also need to bear losses caused by high risk innovation, increase current expenses which ultimately will have impact on overall performance.

Central enterprises have large scale, multi-layer management and complex structure; excessive bureaucratic control leads to loss of marginal control, resulting in the decline in R\&D efficiency (Legge, 2000). Bureaucracy also leads to more time and efforts spent on coordinating research activities, manufacturing activities and marketing activities, therefore some potential market opportunities could be missed (Song, 1998). In addition, income per unit of R\&D spending is relatively low due to large enterprises' cost allocation mechanism, leading to a reduction of R\&D efforts and eventually decline in R\&D performance (Cohen, 1996).

Hall (2006) finds out that there is a negative correlation between percentage of shares held by the largest shareholder and innovation performance through research of listed manufacturing companies in France, Germany and Italy. Research by Feng, Gengfu, Wen, Jun (2008) and Wu, Yanbing (2008) also testified that there is a negative relationship between percentage of state-owned ownership (including state-owned shares and state-owned legal persons shares) and technological innovation of enterprises. Stateowned ownership also can reduce incentive to promote innovation (Li, Chuntao; Song, Ming 2010). The features such as high percentage of state-owned shareholders in central enterprises and strong controlling power of big shareholders will cause a decline in R\&D performance.

Obviously, assessment will work as guidance. When enterprises find out that $R \& D$ investment cannot help to improve efficiency in short term, especially it is more difficult to improve performance under the background of severe bureaucracy and concentrated ownership, their motivation to invest in $R \& D$ is dramatically reduced. Eventually this unwilling to invest in $R \& D$ will reduce technological innovation effort and related resources allocation, resulting in the decline of innovation ability of enterprises.

In conclusion, we made the following assumptions:

H1: There is a negative correlation between central enterprises R\&D investment and performance;

$\mathrm{H} 2$ : There is a negative correlation between central enterprises R\&D personnel and performance;

$\mathrm{H} 3$ : The annual assessment is not beneficial for central enterprises to improve innovation ability.

2) Three-year $R \& D$ investment and performance: $\mathrm{R} \& \mathrm{D}$ and innovation is long-term work. Modern enterprises treat technological innovation as a strategic investment and current innovation investment is to obtain long term benefit. Enterprises have intellectual property and technology secret after R\&D success so that enterprises become independent from external technological resource and achieve future sustainable competition advantage through building up technical barriers (Cassiman, 2000). Prahalad and Hamel (1990) believe that the core competence of enterprises is a combination of technology, knowledge, and capability. These capabilities mainly rely on long-term technical innovation. Enterprises which have strong innovation capability will have strong capability to converse core competence into competition advantage and enterprises will have long term stable benefit. Therefore, from long term point of view, innovation is positively correlated to enterprise performance.

Lee (1996) found that there is a lag period between $R \& D$ investment and performance improvement by studying Korean companies. He, Wei (2003) also believed that there is a lag period for technical development cost of large and medium-size industrial enterprises in China. Liang, Laixin and Zhang, Huanfeng (2005) also find that it generally takes more than two years for $\mathrm{R} \& \mathrm{D}$ investment to become effective based on domestic research. In addition, different intensity of investment brings different lag periods and lower intensity of investment becomes effective more slowly.

As large corporations, central enterprises have the ability to obtain ample innovation resources. In long term, central enterprises can explore the optimal R\&D investment portfolio, diversify risk and add value to its products (Henderson, 1997). In large corporations, R\&D activities can 
easily become complementary to marketing activities (Cohen, 1995). The longer the time, the greater the probability of the complementary will be, and the higher the economic benefit of new products can obtain (Griffin and Hause, 1996).

The appraisal period for managers of central enterprises is 3 years. In the context of the period appraisal, because longer term R\&D investment will help improve performance, managers of central enterprises are encouraged to focus on long term interest, increase investment in $R \& D$, thereby enhance the ability of technical innovation and push the change of development mode.

In conclusion, we make the following assumptions:

H4: Three-year R\&D investment is positive correlated to performance of central enterprises;

H5: Three-year R\&D personnel input are positive correlated to performance for central enterprises;

H6: Period appraisal is beneficial for central enterprises to improve innovation ability.

\section{EMPIRICAL RESEARCH}

\section{A. Sample Selection}

The article chose one hundred and seventy seven listed central enterprises holding companies in Shanghai and Shenzhen Stock Exchange from 2007 to 2009. Because about $80 \%$ of high-quality assets in central enterprises are already injected in the listed entities, it has practical significance to select listed central enterprises holding companies as research samples. The sample enterprises data is from Wind database. Forty five out of the one hundred and seventy seven research samples have published $R \& D$ investment data through their annual reports in three consecutive years. We have collected Panel Data in three years balance, of which one hundred and thirty five are valid observation points.

\section{B. Variable Selection}

Explained variable: EVA. EVA is the value after deducting cost of capital and cost of debt from its after-tax operating profit. Compared with the traditional accounting figure, EVA can more practically reflect the efficiency of capital usage and the capability to create value for enterprises, and reflect the operating performance more objectively (Stewart, 1991). Calculation methods refer to relevant provisions of SASAC.

Explanatory variables: R\&D investment \% (r\&d), Personnel \% (sd).

Control variables: Accounts receivable turnover ratio (ys), Earned interest multiple (ir), Non-current assets ratio (fl), Assets scale (zc), Loan and deposit turnover ratio (ch), and Industry (industry).

The difficulty of this article is to build a 3-year EVA framework. In order to solve the issue, we regard period from 2007 to 2009 as a cycle and treat 3-year EVA formula the same as annual EVA. We first divide the calculated required indicators into point indicators and period indicators, with the ending balance of point indicators (such as indicators on balance sheet) being the end of 2009 figures, average value of point indicators is the average of beginning value of 2007 and ending value of 2009, and value of period indicators are 3-year figures in total. Please see Table 1 for index value and calculation methods, Table 2 and Table 3 for statistic description and Pearson correlation coefficient.

TABLE I. EVA AND VARIABLE COMPUTATION

\begin{tabular}{|c|c|c|}
\hline Name & 1-year Cycle & 3-year Cycle \\
\hline Net Profit & Current Net Profit & $\sum$ Net Profit \\
\hline $\begin{array}{l}\text { Interest } \\
\text { Expenses }\end{array}$ & $\begin{array}{l}\text { Current Interest } \\
\text { Expenses }\end{array}$ & $\sum$ Interest Expenses \\
\hline $\begin{array}{l}\text { Average } \\
\text { Owner's Equity }\end{array}$ & $\begin{array}{l}\text { (Owner's equity at the } \\
\text { beginning + Owner's } \\
\text { equity at the end) } / 2\end{array}$ & $\begin{array}{l}\text { (Owner's equity at the } \\
\text { beginning of } 2007+\text { Owner's } \\
\text { equity at the end of 2009) } / 2\end{array}$ \\
\hline $\begin{array}{l}\text { Average } \\
\text { Liability }\end{array}$ & $\begin{array}{l}\text { (Liability at the } \\
\text { beginning }+ \text { Liability at } \\
\text { the end) } / 2\end{array}$ & $\begin{array}{l}\text { (Liability at the beginning of } \\
2007+\text { Liability at the end of } \\
2009) / 2\end{array}$ \\
\hline $\begin{array}{l}\text { Average non- } \\
\text { interest bearing } \\
\text { liability }\end{array}$ & $\begin{array}{l}\text { (Non-interest bearing } \\
\text { liability at the beginning } \\
+ \text { non-interest bearing } \\
\text { liability at the end)/2 }\end{array}$ & $\begin{array}{l}\text { (Non-interest bearing } \\
\text { liability at the beginning of } \\
2007+\text { non-interest bearing } \\
\text { liability at the end of 2009)/2 }\end{array}$ \\
\hline $\begin{array}{l}\text { Average } \\
\text { projects under } \\
\text { construction }\end{array}$ & $\begin{array}{l}\text { (Projects under } \\
\text { construction at the } \\
\text { beginning + projects } \\
\text { under construction at the } \\
\text { end) } / 2\end{array}$ & $\begin{array}{l}\text { (Projects under construction } \\
\text { at the beginning of } 2007+ \\
\text { projects under construction at } \\
\text { the end of 2009) /2 }\end{array}$ \\
\hline $\begin{array}{l}\text { R\&D expense } \\
\text { adjustment }\end{array}$ & $\begin{array}{l}\text { Current R\&D expenses } \\
\text { adjustment }\end{array}$ & $\sum \mathrm{R} \& \mathrm{D}$ expenses adjustment \\
\hline $\begin{array}{l}\text { Non-recurring } \\
\text { revenue } \\
\text { adjustment }\end{array}$ & $\begin{array}{l}\text { Current non-recurring } \\
\text { revenue adjustment }\end{array}$ & $\begin{array}{l}\sum \text { Current non-recurring } \\
\text { revenue adjustment }\end{array}$ \\
\hline $\mathrm{R} \& \mathrm{D} \%$ (r\&d) & $\begin{array}{l}\text { Current R\&D / } \\
\text { Operating Income }\end{array}$ & $\begin{array}{l}\sum \mathrm{R} \& \mathrm{D} / \sum \text { Operating } \\
\text { Income }\end{array}$ \\
\hline $\begin{array}{l}\text { Technical } \\
\text { Staff \% (sd) }\end{array}$ & $\begin{array}{l}\text { Technical staff / Total } \\
\text { staff }\end{array}$ & $\begin{array}{l}\sum \text { Technical staff at the end / } \\
\sum \text { Total staff at the emd }\end{array}$ \\
\hline $\begin{array}{l}\text { Accounts } \\
\text { Receivable } \\
\text { turnover } \\
\text { ratio(ys) }\end{array}$ & $\begin{array}{l}\text { Main business income / } \\
\text { Average accounts } \\
\text { receivables }\end{array}$ & $\begin{array}{l}\text { ¿Main business income / } \\
\text { [(Accounts receivable at the } \\
\text { beginning of } 2007+ \\
\text { Accounts receivable at the } \\
\text { end of 2009)/2] }\end{array}$ \\
\hline $\begin{array}{l}\text { Interest earned } \\
\text { multiple(ir) }\end{array}$ & $\begin{array}{l}\text { Earnings before interest } \\
\text { and expenses/ Interest } \\
\text { expenses }\end{array}$ & $\begin{array}{l}\sum \text { Earnings before interest } \\
\text { and expenses } / \sum \text { Interest } \\
\text { expenses }\end{array}$ \\
\hline $\begin{array}{l}\text { Non-current } \\
\text { assets \%(fl) }\end{array}$ & $\begin{array}{l}\text { Non-current assets / } \\
\text { Total assets }\end{array}$ & $\begin{array}{l}\text { Non-current assets at the end } \\
\text { of } 2009 \text { / Total assets at the } \\
\text { end of } 2009\end{array}$ \\
\hline Asset Size(zc) & $\begin{array}{l}\text { Ln (Total assets at the } \\
\text { end) }\end{array}$ & $\begin{array}{l}\ln (\text { Total assets at the end of } \\
2009)\end{array}$ \\
\hline $\begin{array}{l}\text { Inventory } \\
\text { turnover } \\
\text { rate(ch) }\end{array}$ & $\begin{array}{l}\text { Operating Costs / } \\
\text { Average Inventory }\end{array}$ & $\begin{array}{l}\text { LOperating Costs / } \\
\text { [(Inventory at the beginning } \\
\text { of } 2007+\text { Inventory at the } \\
\text { end of } 2009) / 2]\end{array}$ \\
\hline
\end{tabular}


TABLE II. STATISTIC DESCRIPTION OF INDICATORS IN 1-YEAR CYCLE AND THE PEARSON CORRELATION COEFFICIENT

\begin{tabular}{|l|l|l|l|l|l|l|l|l|l|l|}
\hline & Avg & Stdev & eva & r\&d & Sd & ys & ir & fl & zc & ch \\
\hline eva & 2.09 & 7.6266 & 1.0000 & & & & & & & \\
\hline r\&d & 1.95 & 2.455 & -0.0950 & 1.0000 & & & & & & \\
\hline sd & 18.82 & 13.941 & -0.1548 & 0.1541 & 1.0000 & & & & & \\
\hline ys & 14.66 & 29.4189 & 0.2226 & -0.1123 & -0.1642 & 1.0000 & & & & \\
\hline ir & 12.29 & 27.4287 & 0.4904 & -0.0381 & -0.0906 & -.0896 & 1.0000 & & & \\
\hline fl & 0.39 & 0.1403 & -0.1355 & -0.0282 & -0.1759 & 0.1121 & 0.0791 & 1.0000 & & \\
\hline zc & 21.62 & 1.3174 & 0.2178 & -0.3008 & -0.1458 & 1.4447 & -0.0329 & 0.3402 & 1.0000 & \\
\hline ch & 6.18 & 5.9914 & 0.0837 & -0.3035 & -0.2118 & 0.2447 & 0.1003 & 0.4512 & 1.3313 & 1.0000 \\
\hline
\end{tabular}

TABLE III. STATISTIC DESCRIPTION OF INDICATORS IN 3-YEAR CYCLE AND THE PEARSON CORRELATION COEFFICIENT

\begin{tabular}{|l|l|l|l|l|l|l|l|l|l|l|}
\hline & Avg & Stdev & eva & r\&d & sd & ys & ir & fl & zc & ch \\
\hline eva & 6.42 & 19.6439 & 1.0000 & & & & & & & \\
\hline r\&d & 1.96 & 2.1197 & -0.0024 & 1.0000 & & & & & & \\
\hline sd & 18.82 & 13.4461 & -0.2284 & 0.2366 & 1.0000 & & & & & \\
\hline ys & 9.84 & 281.983 & 0.1689 & 0.0784 & -0.0935 & 1.0000 & & & & \\
\hline ir & 9.84 & 281.983 & -0.1233 & 0.1231 & 0.2229 & -0.1181 & 1.0000 & & & \\
\hline fl & 0.37 & 0.1386 & 0.0240 & -0.0358 & -0.2092 & 0.0056 & -0.0774 & 1.0000 & & \\
\hline zc & 21.88 & 1.3701 & 0.3386 & -0.3572 & -0.1912 & 0.0162 & -0.2278 & 0.3220 & 1.0000 & \\
\hline ch & 20.22 & 15.6616 & 0.1846 & -0.3653 & -0.1668 & 0.2167 & -0.1980 & 0.5272 & 0.3151 & 1.0000 \\
\hline
\end{tabular}

\section{Model Design}

1) EVA in 1-year cycle as explanatory variables to establish the following models:

$$
\begin{aligned}
& \text { eva }=\beta_{0}+\beta_{1} r \& d+\beta_{2} y s+\beta_{3} i r+\beta_{4} f l+\beta_{5} z c+\beta_{6} c h+\beta_{7} \text { industry }+\varepsilon \\
& \text { eva }=\beta_{0}+\beta_{1} s d+\beta_{2} y s+\beta_{3} i r+\beta_{4} f l+\beta_{5} z c+\beta_{6} c h+\beta_{7} \text { industry }+\varepsilon \\
& \text { eva }=\beta_{0}+\beta_{1} r \& d+\beta_{2} s d+\beta_{3} y s+\beta_{4} i r+\beta_{5} f l+\beta_{6} z c+\beta_{7} c h+\beta_{8} \text { industry }+\varepsilon
\end{aligned}
$$

2) EVA in 3-year cycle as explanatory variables to establish the following models:

$$
\begin{aligned}
& e v a_{3}=\beta_{0}+\beta_{1} r \& d+\beta_{2} y s+\beta_{3} i r+\beta_{4} f l+\beta_{5} z c+\beta_{6} c h+\beta_{7} \text { industry }+\varepsilon \\
& e v a_{3}=\beta_{0}+\beta_{1} s d+\beta_{2} y s+\beta_{3} i r+\beta_{4} f l+\beta_{5} z c+\beta_{6} c h+\beta_{7} \text { industry }+\varepsilon \\
& e v a_{3}=\beta_{0}+\beta_{1} r \& d+\beta_{2} s d+\beta_{3} y s+\beta_{4} i r+\beta_{5} f l+\beta_{6} z c+\beta_{7} c h+\beta_{8} i n d u s t y+\varepsilon
\end{aligned}
$$

\section{Test Results}

Treat annual EVA and 3-year EVA as explanatory

\begin{tabular}{|c|c|c|c|c|c|c|}
\hline & \multicolumn{3}{|c|}{ 1-year cycle (annual EVA as explanatory variables) } & \multicolumn{3}{|c|}{ 3-year cycle (3-year EVA as explanatory variables) } \\
\hline & Model 1 & Model 2 & Model 3 & Model 4 & Model 5 & Model 6 \\
\hline r\&d & $-0.3368 *$ & & $-0.3452 *$ & $0.9824 *$ & & $1.1320^{*}$ \\
\hline sd & $(-1.93)$ & & $(-1.91)$ & $(1.82)$ & & $(1.73)$ \\
\hline ys & $\begin{array}{l}0.5321^{*} \\
(1.66)\end{array}$ & $\begin{array}{l}0.0477 \\
(1.46)\end{array}$ & $\begin{array}{l}0.0541 \text { ** } \\
(1.67)\end{array}$ & $\begin{array}{l}0.0152 * \\
(1.66)\end{array}$ & $\begin{array}{l}0.0149 * \\
(1.72)\end{array}$ & $\begin{array}{l}0.0129 * \\
(1.67)\end{array}$ \\
\hline ir & $\begin{array}{l}0.0232 * \\
(1.92) \\
\end{array}$ & $\begin{array}{l}0.0247 * * \\
(2.0) \\
\end{array}$ & $\begin{array}{l}0.0233 * * \\
(1.92) \\
\end{array}$ & $\begin{array}{l}-0.0018 \\
(-0.39) \\
\end{array}$ & $\begin{array}{l}-0.007 \\
(-0.13) \\
\end{array}$ & -0.000465 \\
\hline fl & $\begin{array}{l}-1.6133 \\
(-0.26)\end{array}$ & $\begin{array}{l}-1.6222 \\
(-0.25)\end{array}$ & $\begin{array}{l}-1.4849 \\
(-0.23)\end{array}$ & $\begin{array}{l}-19.9436^{*} \\
(-1.7)\end{array}$ & $\begin{array}{l}-19.4084^{*} \\
(-1.85)\end{array}$ & $\begin{array}{l}-25.9565^{* *} \\
(-2.03)\end{array}$ \\
\hline $\mathrm{zc}$ & $\begin{array}{l}0.0266 \\
(0.02) \\
\end{array}$ & $\begin{array}{l}0.1029 \\
(0.08) \\
\end{array}$ & $\begin{array}{l}0.0669 \\
(0.05) \\
\end{array}$ & $\begin{array}{l}2.1523^{*} \\
(1.91)\end{array}$ & $\begin{array}{l}2.0090 * \\
(1.80)\end{array}$ & $\begin{array}{l}2.4759 * * \\
(2.18)\end{array}$ \\
\hline $\mathrm{ch}$ & $\begin{array}{l}0.0129 \\
(0.11) \\
\end{array}$ & $\begin{array}{l}0.0035 \\
(0.03) \\
\end{array}$ & $\begin{array}{l}0.0070 \\
(0.06) \\
\end{array}$ & $\begin{array}{l}0.0959 \\
(0.79) \\
\end{array}$ & $\begin{array}{l}0.0718 \\
(0.62) \\
\end{array}$ & $\begin{array}{l}0.1469 \\
(1.18) \\
\end{array}$ \\
\hline Constant & $\begin{array}{l}2.9749 \\
(0.11)\end{array}$ & $\begin{array}{l}1.5002 \\
(0.05)\end{array}$ & $\begin{array}{l}2.4391 \\
(0.01)\end{array}$ & $\begin{array}{l}-59.3458 * * \\
(-2.02)\end{array}$ & $\begin{array}{l}-54.5634 * * \\
(-2.24)\end{array}$ & $\begin{array}{l}-64.4343 * * \\
(-2.60)\end{array}$ \\
\hline Industry & Control & Control & Control & Control & Control & Control \\
\hline $\mathrm{F}$ & 27.84 & 26.25 & 24.76 & 24.35 & 24.08 & 22.74 \\
\hline R-sq & 0.7557 & 0.7447 & 0.7726 & 0.8269 & 0.8252 & 0.8317 \\
\hline Hausman Test & 34.28 **** & $40.74 * * *$ & $76.61 * * *$ & & & \\
\hline Model Type & $\begin{array}{l}\text { Fixed } \\
\text { effects }\end{array}$ & Fixed effects & Fixed effects & & & \\
\hline
\end{tabular}
variables, substitute into (3.1), (3.2), (3.3) and (3.4), (3.5), (3.6) respectively and use Stata 11.0 panel and crosssectional data analysis. The regression results are shown in Table 4:

TABLE IV. REGRESSION RESULTS

Note: $* * *, * *, *$ are respectively significant on 2-tailed levels of $1 \%, 5 \%$ and $10 \%$, the value in brackets are t value after the heteroskedasticity adjustment, White (1980).
1) Annual R\&D investment is negatively correlated to EVA

From Table 4 we can see that model 1 and 3 both show that current R\&D investment is negative correlated to EVA 
( $\beta$ is -0.3368 and -0.3452 respectively, $\mathrm{p}<10 \%$ ) and models are stable. This has validated the hypothesis. Although R\&D cost factor is eliminated when calculating EVA, enterprises focusing on improving innovation capacity will form innovation-oriented business model which is from inside to outside and technology driven (Yang, Zhi 2009). Enterprises are going to focus more on products innovation and refinement (Berthon, 1999) which will affect the performance. Indicator of the technical staff to total staff ratio (sd) did not pass the significance test, which is contrary to the expectation. There are no uniform disclosure rules of technical staff for listed companies by China Securities Regulatory Commission (CSRC) according to telephone interview, therefore the number of technical staff disclosed in annual reports of sample enterprises may be counted based on dramatically different methods: some enterprises identify technical staff based on positions; some enterprises identify technical staff based on professional titles; some enterprises identify all the staff in technology, R\&D departments (including administrative and supportive staff) as technical staff. There is no comparability for technical staff proportion indicators among sample enterprises due to a lack of unified counting methodology.

Through the establishment of incentive and constraint mechanism, assessment has guided enterprise management and management behavior. EVA was given $40 \%$ weight in annual assessment of central enterprises. Central enterprises which were evaluated are determined to reduce R\&D investment due to the negative correlation between $R \& D$ investment and current EVA performance. This is not to the benefit of improving enterprises innovation capability, neither is it helpful to change enterprises development mode. Therefore this has validated $\mathrm{H} 3$ assumption.

2) 3-year $R \& D$ investment is positively correlated to EVA, and the correlation is significant.

From Table 4 we can see that model 4 and 5 both show positive correlation between 3-year R\&D investment and 3year performance ( $\beta$ is 0.9824 and 1.132 respectively, $\mathrm{p}<10 \%)$ and models are stable when 3-year EVA is explained variable. In long term, business managers are more willing to focus on long-term benefits and increase R\&D investment, therefore support $\mathrm{H} 4$ assumptions. Indicator of the technical staff to total staff ratio (sd) has not passed the significance test due to the same reasons mentioned above.

Under the assessment driven mechanism, if we introduce 3-year term EVA assessment, managers will be encouraged to increase R\&D investment, promote innovation capability and change development mode for long term benefit, because of the positive correlation between R\&D investment in office term and EVA. This has validated H6 assumption.

\section{RESEARCH CONCLUSION AND POLICY RECOMMENDATION}

The paper has chosen 3-year continuously disclosed R\&D costs of 45 listed companies controlled by central enterprises from 2007 to 2009 as research samples, established annual and 3-year EVA research frameworks, and studied relationship between enterprises R\&D investment by different cycles and EVA. Studies have shown that:

1) Annual $R \& D$ investment by central enterprises is negative correlated to EVA and the correlation is significant. The higher the current R\&D investment to operating profits ratio, the greater the negative impact on current EVA. The assessment of EVA does not help improve innovation capacity of central enterprises.

2) 3-year R\&D investment by central enterprises is positive correlated to EVA and the correlation is significant. The higher the 3 -year R\&D investment to operating profits ratio, the greater the positive impact on 3-year EVA. The assessment of EVA does help improve innovation capacity of central enterprises.

According to above analysis, we believe that SASAC shall pay attention to below questions when evaluate EVA performance:

(1) Implement different annual EVA performance assessment.

American scholars Linda \& Michael (2002) find that enterprises have low intention to adopt EVA assessment while have high R\&D investment based on study of one thousand nine hundred and seventy one American enterprises. This article explains the phenomenon from one side. SASAC has implemented the annual EVA performance assessment in 2010 for performance assessment of managers in charge of central enterprises. Because R\&D investment is negatively correlated to annual EVA, it is detrimental to central enterprises to increase input in technology innovation and improve innovation capacity, and it affects more on those enterprises which is more dependent on high-tech, IT and R\&D investment. It is recommended to implement different assessment methods to central enterprises according to different industry characteristics, accordingly adjust WACC as well as the scope of projects, furthermore encourage enterprises technical innovation.

(2) Introduce term EVA assessment.

SASAC has issued < < Interim Measures for Assessment of the Operational Performance of Persons in Charge of Central Enterprises $>$ in early 2010. There is no EVA measure in term assessment indicators. According to this research, 3-year R\&D investment is positively correlated to 3-year EVA. If EVA measure is introduced as 3-year assessment of the operational performance of managers in charge of central enterprises, it will encourage central enterprises to focus on long-term R\&D investment, technical innovation and resource allocation, help avoid short-term "short-sight" and help enhance innovation capacity. It is recommended for SASAC to optimize the term assessment indicators of central enterprises, introduce 3-year term EVA assessment, and encourage enterprises innovation. Meanwhile, it is recommended to rationally design the calculation method of point index and period index for term EVA assessment. 


\section{REFERENCES}

[1] Yu, Liping: Research on EVA of Production Industry in China (J), Economist, 2007 (4):114-120.

[2] Ru, Zhiguo: Transmission Mechanism Analysis of R\&D Investment Effect on Technology Innovation (J), Shenzhen University Study Paper (Humanities and Social Science), 2005 (9): 25-29.

[3] Li, Ping; Cui, Xijun; Liu, Jian: R\&D Capital Input-Output Performance Analysis of Independent Innovation in China (J), Social Science of China, 2007 (3); 32-42.

[4] Zvi G. Market Value, R\&D, and Patents [J]. Economic Letters, 2000(7) : 183-187.

[5] Bosworth, Rogers . Market value, R\&D and intellectual property:an empirical analysis of large Australian firms [J] .The Economic Record, 2001(12) : 323-337.

[6] Ping-Huang H. , Chandras M. , David. H. Gobell. The return on $R \& D$ versus capital expenditure in pharmaceutical and chemical industries $[\mathrm{J}]$. Transaction Engineering Management, 2003, May : 141-150.

[7] Bong H. H. , David M. The value-relevance R\&D and advertising expenditures : evidence from Korea The International Journal of Accounting, $2004: 39-173$.

[8] Cheng, Hongwei; Zhang, Yonghai; Chang, Yong: Empirical Research on the Relationship between Company R\&D and Performance (J), Scientific Management Research, 2006(6): 110-113

[9] Lin B. W. , Lee Y. , Hung S. C., R\&D intensity and commercialization orientation effects on financial performance[J]. Journal of Business Research, 2006(59) : 679-685.

[10] Liang, Laixin; Zhang, Huangfeng: Empirical Research on Inputs Performance of R\&D Investment by High-tech Companies (J), Zhongnan University Study Paper (Social Science), 2005 (4): 222224.

[11] Liang, Laixin; Jin, Yang; Zhao, Na: Research on Relationship between R\&D investment based on Enterprise Lifecycle and Enterprise Performance (J), Science and Scientific Management, 2010 (12): 11-18.

[12] Mumfordamd D. Managing creative people: strategies and tactics for innovation [J]. Human Resource Management Review, 2000, 10(3): 313-351.

[13] Yao, Yang; Zhang, Qi: The Enterprise Technical Efficiency Analysis for China's Industry (J), Economy Research 2001(10): 13-95.

[14] Tsai K . H . R\&D productivity and firm size: a nonlinear examination[J]. Technnovation, 2005(25) : 795-803.

[15] Tsaik K. H. , WANG J. C. , Does R\&D performance decline with firm size?-A re-examination in terms of elasticity[J]. Research Policy, 2005(34) : 966-976

[16] Legge J. M. , The economics of industrial innovation[J]. Review of Political Economy, 2000, 12(2) : 249-256.

[17] Song X. M. , Thieme R. J. , XIE J. The impact of crossfunctional joint involvement across product development stages: an exploratory study[J].Journal of Product Innovation Management,1998(15):289-303.

[18] Cohen W . M . , Klepper S . A reprise of size and R\&D[J] . Economic Journal, 1996(106) : 925-952.

[19] Hall B. H. ,Oriani R. , Does the market value R\&D investment by European firms? Evidence from a panel of manufacturing firms in France, Germany, and Italy[J]. International Journal of Industrial Organization, 2006(24) : 971-993.

[20] Feng, Genfu; Wen, Jun: Practical Research on the Relationship between Governance of Listed Companies in China and Enterprise Technology Innovation (J), Industrial Economy in China 2008 (7): 91-101.

[21] Wu, Yanbing: The Output Elasticity Estimates of R\&D in China's Industry (J), Economics (Quarterly), 2008, 7 (3): 869-890.

[22] Li, Chuntao; Song, Min: The Innovation Activity of Enterprises in Manufacturing Industry in China(J), Economic Research, 2010 (5): 55-67.

[23] Cassiman B, Veugelers R. External technology sources: embodied or disembodied technology acquisition $[\mathrm{M}]$. Universitat Pompeu Fabra ,Barcelona ,Spain , 2000.

[24] Prahalad C. K. and Hamel G. , The core competence of the corporation Harvard business review ，68(3), 1990, 79-91.

[25] Lee M, et al. Measuring R\&D effectiveness in korean companies [J]. Research Technology Management, 1996(6) : 19-25.

[26] He, Wei: The effect of R\&D input by China's large and medium size Enterprises on Output (J), Economic Science, 2003 (3): 5-11.

[27] Henderson R, Cockburn I. Firm size and research productivity in drug discovery [A]. In: JACOBZONE S.(Ed.).La Sant'e:Trajectoires D'avenir.INSEE[C].Paris, 1997.

[28] Cohen W. M. Empirical studies of innovative activity[A]. In : STONEMAN . (Ed). Handbook of the economics of innovationand technological change[C].Boston:Blackwell, 1995.

[29] GRIFFIN A,HAUSER J R.Integrating R\&D and marketing: a review and analysis of the literature[J].Journal of Product Innovation Management,1996(13):191-215.

[30] Stewart. The Quest for Value: A Guide for Senior Managers [M]. New York: Harper Business, 1991. 91

[31] Yang, Zhi; Yu, Shenfeng; Xiang, Bing: The impact of Strategic Orientation of the Enterprises on Performance: Innovation as Mediating Variables (J), Science and Scientific Management, 2009(7): 156-163.

[32] Berthon, P., Hulbert J. M, Pittl F. To Serve or Create Strategic Orientations Toward Customers and Innovation [J]. California Management Review, 1999, 42(1):37-58.

[33] Linda M. Lovata and Michael L.Costigan. Empirical analysis of adopters of economic value added [J].Management Accounting Research,2002,13:215-228. 